\title{
Vaccination of mice with lipopolysaccharide (LPS) and LPS-derived immuno-conjugates from Leptospira interrogans
}

\author{
A. MIDWINTER, S. FAINE and B. ADLER* \\ Department of Microbiology, Monash University, Clayton, 3168, Victoria, Australia
}

\begin{abstract}
Summary. Mice were vaccinated with lipopolysaccharide (LPS) from Leptospira interrogans serovar pomona or hardjo, or with the polysaccharide (PS) fraction of the LPS, or with an immunoconjugate of PS and diphtheria toxoid (DT). Maximum agglutinin titres were found 6-10 weeks after vaccination with LPS or PS-DT conjugate; the latter elicited antibody titres at least 10 times higher than those produced in response to LPS. Animals failed to react significantly to PS. Titres elicited by antigens of serovar pomona were higher than those elicited by serovar hardjo.
\end{abstract}

\section{Introduction}

Leptospirosis is an acute febrile illness caused by serovars of Leptospira interrogans. The two most commonly associated with disease in Australia and New Zealand are serovars pomona and hardjo. ${ }^{1,2}$ Immunity to infection by $L$. interrogans depends on the production of serum agglutinins $s^{3,4}$ against leptospiral antigens. Many antigen preparations have been studied, ${ }^{5}$ the most significant being lipopolysaccharide (LPS). Leptospiral LPS has chemical and biological properties different from those of the classical LPS of gram-negative organisms such as Escherichia coli, ${ }^{6-8}$ and appears to be neither toxic nor pyrogenic. Monoclonal antibody (MAb) against a polysaccharide epitope of leptospiral LPS protected guinea-pigs passively against leptospirosis, ${ }^{9}$ and MAbs against LPS determinants are opsonic. ${ }^{10}$ Furthermore, leptospiral LPS is a major antigen recognised by human antibodies produced in response to infection with L. interrogans. ${ }^{11}$ Immunisation with leptospiral LPS or the polysaccharide (PS) fraction of LPS from serovar copenhageni protected hamsters from lethal challenge with virulent organisms of the same serovar. ${ }^{12}$ This suggests that LPS antigens could be used as immunising agents against leptospirosis. The LPS and PS of leptospires appear to be T-cellindependent antigens which elicit mainly IgM responses. ${ }^{12,13}$ The covalent binding of carbohy-

Received 7 March 1990; accepted 7 May 1990.

* Correspondence should be addressed to Dr B. Adler. drate antigens to antigenic proteins, first described in 1929 by Avery and Goebel, ${ }^{14}$ confers T-celldependent properties on several polysaccharide antigens, ${ }^{15-18}$ offering an attractive method for increasing the immunogenicity of such antigens and for stimulating a longer-lived IgG response. The aim of this study was to investigate the serological responses of mice to LPS and PS antigen preparations of serovars pomona and hardjo and to prepare and assess the potential of PS-protein conjugate preparations as immunising agents against leptospirosis.

\section{Materials and methods}

\section{Bacteria, antigens and serological methods}

Leptospira interrogans serovar pomona strain L10 was isolated from a human case of leptospirosis. ${ }^{19}$ Serovar hardjo strain L13 was the Hardjoprajitno reference strain $^{20}$ obtained in 1979 from the National Health Institute, Wellington, New Zealand. Cultivation of leptospires and the microscopic agglutination test (MAT) were performed as described previously. ${ }^{21}$ Briefly, serial two-fold dilutions of sera were incubated with viable leptospires at $28^{\circ} \mathrm{C}$ for $1 \mathrm{~h}$ and agglutination determined by examining a loopful on a glass slide by dark-field microscopy. LPS and PS were prepared from both serovars as described previously. ${ }^{9}$ Antiserum against whole leptospires was produced by giving mice $2 \times 10^{8}$ live leptospires by intraperitoneal injection on two occasions with a 2 -week interval; mice were bled 4 weeks after the second injection. MAb that was used has been described previously. ${ }^{22}$ 


\section{Preparation of polysaccharide and diphtheria toxoid (PS-DT) conjugates}

This was based on the method of Schneerson $e t$ al..$^{23}$ The PS fraction of the LPS of serovar pomona or serovar hardjo was dissolved in $0.2 \mathrm{M} \mathrm{NaHCO}(\mathrm{pH} 9.5)$ to give a $1 \mathrm{mg} / \mathrm{ml}$ solution which was stirred over ice while cyanogen bromide $1 \mathrm{mg} / \mathrm{mg}$ of polysaccharide was added. After $6 \mathrm{~min}$, adipic acid dihydrazide (Sigma) dissolved in $0.5 \mathrm{M} \mathrm{NaHCO}$ was added to a final concentration of $0.3 \mathrm{M}$. The $\mathrm{pH}$ was adjusted to 8.5 with $0.2 \mathrm{M} \mathrm{HCl}$ and the reaction mixture was stirred overnight at $4^{\circ} \mathrm{C}$. The solution was dialysed against phosphate-buffered saline, $\mathrm{pH} 7.2$ (PBS) for $72 \mathrm{~h}$ at $4^{\circ} \mathrm{C}$, and lyophilised; the carbohydrate content was assayed by the phenol and sulphuric acid method of Dubois et al. ${ }^{24}$ This activated polysaccharide was stored at $-20^{\circ} \mathrm{C}$.

Diphtheria toxoid (DT) (Commonwealth Serum Laboratories, Melbourne, Australia) $100 \mathrm{Lf} / \mathrm{ml}$ was purified by passing $5-\mathrm{ml}$ samples through a $70-\mathrm{cm}$ column of Sephacryl S-300 Superfine (Pharmacia, LKB Biotechnology AB, Uppsala, Sweden) equilibrated with PBS. Fractions containing the $70-\mathrm{Kda}$ toxoid peak $^{25}$ were pooled, concentrated with an Amicon PM-10 ultrafiltration membrane (Amicon Div., W R Grace \& Co, Danvers, MA, USA) and chromatographed again on Sephacryl S-300. Fractions were pooled and concentrated again and the protein concentration was measured by the micro-method of Bradford. ${ }^{26}$ Purified toxoid was then passed through a sterile $0.45-\mu \mathrm{m}$ filter and stored at $4^{\circ} \mathrm{C}$.

The reaction mixture containing $c .0 \cdot 1 \mathrm{mg}$ of carbohydrate and $0.1 \mathrm{mg}$ of protein per $\mathrm{ml}$ and $0.1 \mathrm{M}$ 1-ethyl-3dimethylaminopropyl carbodiimide (Sigma) was stirred at a constant pH 5.0 over ice for $3 \mathrm{~h}$, and then dialysed against PBS overnight and passed through a column of Sephacryl S-300. The first peak, containing both protein and carbohydrate was concentrated by Amicon PM10 ultrafiltration and filtered through a sterile $0.45-\mu \mathrm{m}$ filter. The carbohydrate and protein content of the conjugated polysaccharide was assayed and the conjugate was stored at $4^{\circ} \mathrm{C}$.

\section{Electrophoresis, transblotting and staining}

Purified DT (100 $\mu \mathrm{g}$ of protein/lane for Coomassie Blue staining or $25 \mu \mathrm{g}$ of protein/lane for Western blotting), PS-DT conjugate (15 $\mu \mathrm{g}$ or $6 \mu \mathrm{g}$ of carbohydrate/lane) and PS (25.5 $\mu \mathrm{g}$ or $64 \mu \mathrm{g}$ of carbohydrate/ lane) were subjected to electrophoresis on 1.0-mm thick, SDS-polyacrylamide $10 \%$ gels (SDS-PAGE) as described by Laemmli ${ }^{27}$ in a Protean I gel apparatus (Bio-Rad, Richmond, CA, USA). Gels were silver-stained for LPS by the method of Hitchcock and Brown, ${ }^{28}$ or stained with Coomassie Blue $0.25 \%$, or the resolved proteins and carbohydrates were transblotted ${ }^{29}$ on to nitrocellulose (Schleicher and Schuell, $0.45 \mu \mathrm{m}$ ) in a Bio-Rad transblot cell and immunostained with anti-LPS MAb, or with mouse antisera against whole leptospires, peroxidaseconjugated rabbit anti-mouse serum (Silenus Laboratories, Melbourne, Australia) and 4-chloro-naphthol. ${ }^{30}$

\section{Vaccination of mice}

Groups of inbred BALB/c mice (Monash University Animal House, Melbourne, Australia) aged 6-8 weeks were given LPS, PS or PS-DT conjugate by subcutaneous injection in $0.1 \mathrm{ml}$ of PBS on days 0 and 14 and were bled at intervals from the orbital plexus.

\section{Results}

\section{Antigenicity of LPS}

In mice vaccinated with LPS, the highest MAT titres were reached after $c .10$ weeks. All mice receiving $25 \mu \mathrm{g}$ of serovar pomona LPS produced detectable antibody by week 10 and this persisted until the end of the study at week 42 (table I). Mice receiving 5-10 $\mu \mathrm{g}$ of LPS did not all react; those receiving $2.5 \mu \mathrm{g}$ or less produced low or undetectable levels of agglutinin.

Mice vaccinated with similar doses of serovar hardjo LPS also showed peak MAT titres after $c .10$ weeks (table II). However, no group showed lasting $100 \%$ sero-conversion, and the average titres were significantly lower than those elicited by pomona LPS. The differences between groups receiving

Table I. Serum agglutinin titres of groups of six mice vaccinated at 0 and 2 weeks with LPS of serovar pomona strain L10

\begin{tabular}{|c|c|c|c|c|c|c|c|}
\hline \multirow{2}{*}{$\begin{array}{c}\text { Weeks } \\
\text { after } \\
\text { vaccination }\end{array}$} & \multicolumn{7}{|c|}{$\begin{array}{l}\text { Geometric mean titre (range) of agglutinin after } \\
\text { vaccination with LPS doses }(\mu \mathrm{g}) \text { of }\end{array}$} \\
\hline & 0.25 & 0.5 & 1.0 & $2 \cdot 5$ & $5 \cdot 0$ & $10 \cdot 0$ & $25 \cdot 0$ \\
\hline 2 & $\begin{array}{c}1 \cdot 2 \\
(0-2)\end{array}$ & 0 & 0 & 0 & 0 & 0 & 0 \\
\hline 3 & 0 & 0 & 0 & 0 & $\begin{array}{c}1 \cdot 3 \\
(0-2)\end{array}$ & $\begin{array}{c}1 \cdot 3 \\
(0-2)\end{array}$ & $\begin{array}{c}1 \cdot 6 \\
(0-2)\end{array}$ \\
\hline 4 & 0 & 0 & 0 & 0 & $\begin{array}{c}1.8 \\
(0-4)\end{array}$ & $\begin{array}{c}4 \cdot 0 \\
(0-32)\end{array}$ & $\begin{array}{c}2 \cdot 6 \\
(0-32)\end{array}$ \\
\hline 5 & 0 & 0 & 0 & 0 & $\begin{array}{c}5 \cdot 3 \\
(0-32)\end{array}$ & $\begin{array}{c}5 \cdot 7 \\
(0-64)\end{array}$ & $\begin{array}{c}4 \cdot 0 \\
(0-32)\end{array}$ \\
\hline 6 & 0 & 0 & 0 & 0 & $\begin{array}{c}3 \cdot 4 \\
(0-16)\end{array}$ & $\begin{array}{c}5 \cdot 0 \\
(0-32)\end{array}$ & $\begin{array}{c}5 \cdot 7 \\
(0-32)\end{array}$ \\
\hline 10 & 0 & 0 & 0 & 0 & $\begin{array}{c}13 \\
(0-128)\end{array}$ & $\begin{array}{c}4 \cdot 8 \\
(0-32)\end{array}$ & $\begin{array}{l}42 \\
(4-256)\end{array}$ \\
\hline 16 & $\begin{array}{c}1 \cdot 4 \\
(0-2)\end{array}$ & 0 & 0 & 0 & $\begin{array}{l}7 \cdot 1 \\
(0-64)\end{array}$ & $\begin{array}{l}6 \cdot 1 \\
(0-128)\end{array}$ & $\begin{array}{l}23 \\
(2-128)\end{array}$ \\
\hline 24 & 0 & 0 & 0 & 0 & $\begin{array}{l}4 \cdot 5 \\
(0-16)\end{array}$ & $\begin{array}{l}3 \cdot 0 \\
(0-64)\end{array}$ & $\begin{array}{l}14 \\
(2-128)\end{array}$ \\
\hline 35 & $\begin{array}{c}1 \cdot 6 \\
(0-4)\end{array}$ & 0 & 0 & $\begin{array}{l}2 \cdot 6 \\
(0-32)\end{array}$ & $\begin{array}{l}11 \\
(0-256)\end{array}$ & $\begin{array}{l}5 \cdot 7 \\
(0-128)\end{array}$ & $\begin{array}{l}26 \\
(2-256)\end{array}$ \\
\hline 42 & 0 & 0 & $\begin{array}{r}2 \cdot 0 \\
(0-4)\end{array}$ & $\begin{array}{c}1 \cdot 6 \\
(0-4)\end{array}$ & $\begin{array}{l}7 \cdot 1 \\
(0-256)\end{array}$ & $\begin{array}{l}6 \cdot 4 \\
(2-32)\end{array}$ & $\begin{array}{l}14 \\
(2-128)\end{array}$ \\
\hline
\end{tabular}

0 , titre $<2$. 
Table II. Serum agglutinin titres of groups of six mice vaccinated at 0 and 2 weeks with LPS of serovar hardjo strain L13

\begin{tabular}{|c|c|c|c|c|c|c|c|}
\hline \multirow{2}{*}{$\begin{array}{l}\text { Weeks after } \\
\text { vaccination }\end{array}$} & \multicolumn{7}{|c|}{$\begin{array}{c}\text { Geometric mean titre (range)* of agglutinin } \\
\text { after } \\
\text { vaccination with LPS doses }(\mu \mathrm{g}) \text { of }\end{array}$} \\
\hline & 0.25 & 0.5 & 1.0 & 2.5 & $5 \cdot 0$ & $10 \cdot 0$ & $25 \cdot 0$ \\
\hline 2 & 0 & 0 & 0 & 2 & 2 & 2 & 4 \\
\hline 3 & 0 & $\begin{array}{c}1 \cdot 3 \\
(0-2)\end{array}$ & 0 & $\begin{array}{l}2 \cdot 8 \\
(0-8)\end{array}$ & $\begin{array}{c}1.5 \\
(0-8)\end{array}$ & $\begin{array}{c}1.2 \\
(0-2)\end{array}$ & 0 \\
\hline 4 & $\begin{array}{c}1 \cdot 3 \\
(0-2)\end{array}$ & 0 & 0 & $\begin{array}{l}1 \cdot 5 \\
(0-4)\end{array}$ & $\begin{array}{c}1 \cdot 1 \\
(0-2)\end{array}$ & 0 & 0 \\
\hline 5 & $\begin{array}{c}1 \cdot 2 \\
(0-2)\end{array}$ & $\begin{array}{c}1 \cdot 3 \\
(0-2)\end{array}$ & $\begin{array}{c}1 \cdot 4 \\
(0-4)\end{array}$ & $\begin{array}{l}1 \cdot 7 \\
(0-16)\end{array}$ & $\begin{array}{l}0 \\
(0-2)\end{array}$ & 1.2 & 0 \\
\hline 6 & $\begin{array}{c}2 \cdot 3 \\
(2-4)\end{array}$ & $\begin{array}{c}2 \cdot 4 \\
(2-4)\end{array}$ & $\begin{array}{c}2 \cdot 2 \\
(0-4)\end{array}$ & $\begin{array}{c}2 \cdot 5 \\
(0-4)\end{array}$ & $\begin{array}{c}2 \cdot 2 \\
(0-8)\end{array}$ & $\begin{array}{c}1.6 \\
(0-8)\end{array}$ & $\begin{array}{l}1 \cdot 8 \\
(0-16)\end{array}$ \\
\hline 10 & 0 & 0 & $\begin{array}{c}1 \cdot 3 \\
(0-2)\end{array}$ & $2 \cdot 0$ & $\begin{array}{c}2 \cdot 6 \\
(2-4)\end{array}$ & $\begin{array}{c}2 \cdot 2 \\
(2-4)\end{array}$ & $\begin{array}{c}3 \cdot 2 \\
(2-8)\end{array}$ \\
\hline 14 & 0 & 0 & $\begin{array}{c}1 \cdot 2 \\
(0-2)\end{array}$ & $\begin{array}{c}1 \cdot 4 \\
(0-4)\end{array}$ & 0 & 0 & $\begin{array}{c}1 \cdot 3 \\
(0-4)\end{array}$ \\
\hline 18 & $\begin{array}{c}1 \cdot 2 \\
(0-2)\end{array}$ & $\begin{array}{c}1 \cdot 3 \\
(0-2)\end{array}$ & $\begin{array}{c}1 \cdot 3 \\
(0-2)\end{array}$ & $\begin{array}{c}1.7 \\
(0-4)\end{array}$ & $\begin{array}{c}3 \cdot 2 \\
(0-8)\end{array}$ & $\begin{array}{c}2 \cdot 3 \\
(0-4)\end{array}$ & $\begin{array}{c}3 \cdot 2 \\
(2-8)\end{array}$ \\
\hline 31 & 0 & $\begin{array}{c}1 \cdot 6 \\
(0-2)\end{array}$ & $\begin{array}{c}1 \cdot 3 \\
(0-2)\end{array}$ & $\begin{array}{c}1.5 \\
(0-2)\end{array}$ & $2 \cdot 0$ & $\begin{array}{c}2 \cdot 0 \\
(0-4)\end{array}$ & $\begin{array}{c}2.5 \\
(0-8)\end{array}$ \\
\hline 39 & ND & ND & ND & $\begin{array}{c}1 \cdot 6 \\
(0-2)\end{array}$ & $\begin{array}{c}1 \cdot 2 \\
(0-2)\end{array}$ & $\begin{array}{c}1 \cdot 2 \\
(0-2)\end{array}$ & $\begin{array}{c}1 \cdot 8 \\
(0-2)\end{array}$ \\
\hline
\end{tabular}

* Where no range is given, all mice had the same titre. 0 , titre $<2$. ND, not done.

different doses of hardjo LPS were not as marked as those with pomona LPS.

Mice vaccinated with a mixture containing equal amounts of LPS from serovars pomona and hardjo reacted to each component similarly to those receiving the individual components. The response to pomona LPS was considerably stronger (mean titre $20 \cdot 2$ at week 6) than to hardjo LPS (mean titre $1 \cdot 4)$. There was neither a synergic nor an antagonistic effect.

\section{Antigenicity of PS}

Mice were inoculated with doses of PS from $0.5 \mu \mathrm{g}$ to $100 \mu \mathrm{g}$. The minimum antigenic dose of PS from serovar pomona was $50 \mu \mathrm{g}$, which produced a seroconversion rate of $20 \%$ with a mean titre of $1 \cdot 1$ at week 10. Mice inoculated with PS from serovar hardjo did not produce detectable antibody.

\section{Examination of PS-DT conjugate}

The carbohydrate and protein content of the conjugated polysaccharides were $240 \mu \mathrm{g} / \mathrm{ml}$ and $262 \mu \mathrm{g} / \mathrm{ml}$ respectively for serovar pomona and
$240 \mu \mathrm{g} / \mathrm{ml}$ and $228 \mu \mathrm{g} / \mathrm{ml}$ respectively for serovar hardjo. PS alone contained less than $5 \%$ protein. The PS-DT conjugates were examined by PAGE and Western blotting (serovar pomona shown in the figure). The PS-DT conjugate was seen as a single discrete band with an apparent mol. wt of $67 \mathrm{Kda}$ detected by Coomassie Blue (lane B) and as an unresolved high mol. wt smear when Western blotted with a MAb against serovar pomona LPS (lane E). The conjugate was distinct from the purified DT (lanes A and F) and from the PS (lanes $\mathrm{C}$ and D). The DT appeared as an unresolved band of 45-66 Kda when stained with Coomassie Blue (lane A) and could not be detected at all when Western blotted with a MAb against a PS epitope of pomona LPS (lane F). In contrast pomona PS did not stain with Coomassie Blue (lane C) but appeared as a single arched band of $30 \mathrm{Kda}$ when Western blotted with the MAb (lane D).

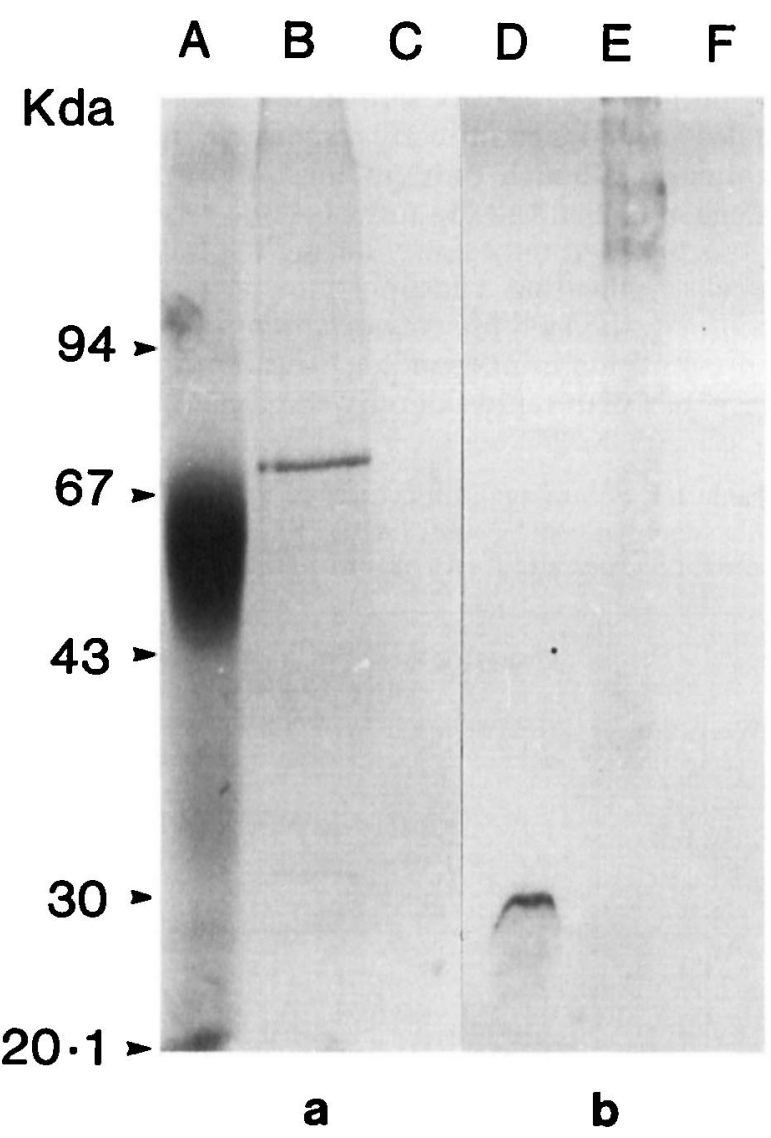

Figure.(a)SDS-PAGE stained with Coomassie Blue; (b) Western blot immunostained with an anti-LPS mouse MAb. Lanes $\mathbf{A}$ and $\mathbf{F}$ : purified DT; $\mathbf{B}$ and $\mathbf{E}$ : pomona $\mathrm{PS}-\mathrm{DT}$ conjugate; $\mathbf{C}$ and D : pomona $\mathbf{P S}$. 


\section{Vaccination with PS-DT conjugate}

Mice were inoculated with PS-DT containing $2 \cdot 4,12.0$ or $48 \mu \mathrm{g}$ of carbohydrate from serovar pomona (table III). All mice seroconverted by week 4 and the mean MAT titres at week 10 were 15-100 times those elicited by the equivalent amount of LPS.

Therefore, mice were inoculated with serovar hardjo PS-DT conjugate containing $2.4 \mu \mathrm{g}$ of carbohydrate-equivalent alone (table III). All mice seroconverted, producing at week 10 a mean MAT titre of 128,40 times the maximum mean titre elicited by LPS.

\section{Discussion}

Previous studies ${ }^{9,10}$ showed that antibodies produced against LPS determinants of Leptospira are protective and that the LPS and PS of some serovars are highly antigenic and protective. ${ }^{12}$ The range of doses tested in this study was equivalent to $c .\left(2.5 \times 10^{7}\right)-\left(2.5 \times 10^{9}\right)$ organisms or $0.25-25 \mu \mathrm{g}$ of LPS. $^{6}$ However not all animals produced agglutinin. The LPS of serovar pomona stimulated a dose-dependent antibody response in most of the animals, although only amongst those receiving $25 \mu \mathrm{g}$ of LPS did all the animals seroconvert. These titres declined only slowly during the following 30 weeks, indicating a lasting immune response. In contrast, the LPS of serovar hardjo produced low, apparently dose-independent titres. The initial high response with rapid fall-off was probably due to a

Table III. Serum agglutinin titres of groups of six mice vaccinated at 0 and 2 weeks with PS-DT conjugate from serovar pomona strain L10 or serovar hardjo strain L13

\begin{tabular}{|c|c|c|c|c|}
\hline \multirow{3}{*}{$\begin{array}{l}\text { Weeks after } \\
\text { vaccination }\end{array}$} & \multicolumn{4}{|c|}{$\begin{array}{l}\text { Geometric mean titre (range) of agglutinin } \\
\quad \text { after vaccination } \\
\text { with conjugate in carbohydrate-doses }(\mu \mathrm{g}) \text { of }\end{array}$} \\
\hline & \multicolumn{3}{|c|}{ serovar pomona } & \multirow{2}{*}{$\begin{array}{c}\text { serovar } \\
\text { hardjo } \\
2 \cdot 4\end{array}$} \\
\hline & $2 \cdot 4$ & $12 \cdot 0$ & $48 \cdot 0$ & \\
\hline 2 & 0 & 0 & 0 & $\begin{array}{c}1 \cdot 6 \\
(0-4)\end{array}$ \\
\hline 4 & $\begin{array}{c}108 \\
(32-512)\end{array}$ & $\begin{array}{c}446 \\
(256-1024)\end{array}$ & $\begin{array}{c}724 \\
(256-2048)\end{array}$ & $\begin{array}{c}10 \\
(4-16)\end{array}$ \\
\hline 6 & $\begin{array}{c}57 \\
(4-512)\end{array}$ & $\begin{array}{c}338 \\
(8-2048)\end{array}$ & $\begin{array}{c}1218 \\
(512-2048)\end{array}$ & $\begin{array}{c}40 \\
(32-64)\end{array}$ \\
\hline 10 & $\begin{array}{c}338 \\
(128-1024)\end{array}$ & $\begin{array}{c}1024 \\
(512-4096)\end{array}$ & $\begin{array}{c}676 \\
(256-2048)\end{array}$ & $\begin{array}{c}128 \\
(32-512)\end{array}$ \\
\hline
\end{tabular}

0 , titre $<2$. short-lived IgM response. Similar differential responses to pomona and hardjo components of wholecell vaccines have been reported previously ${ }^{31,32}$ (see below). Titres achieved with a bivalent preparation containing LPS from both serovars were similar to those from each serovar alone and indicated neither synergic nor antagonistic effects.

Neither the pomona nor hardjo PS induced significant levels of agglutinin. These findings contrast with previous results with serovar copenhageni $^{12}$ in which the PS, although less immunogenic than LPS, could still elicit significant levels of agglutinin and protect from infection. These differences are probably due to intrinsic differences in the chemical composition and structure of the LPS, ${ }^{6,33}$ reflecting significant biological differences between the serovars.

In an effort to improve antigenicity, the PS of the two serovars was linked to DT to produce immunoconjugate vaccines. By gel electrophoresis and Western blotting, the PS-DT conjugate appeared quite distinct from both the purified DT and PS. Although the apparent mol.wt of the PS-DT conjugate was $67 \mathrm{Kda}$ (lane B), somewhat higher than that of the purified DT (lane A), ${ }^{25}$ the apparent mol. wt of the PS ( $30 \mathrm{Kda})$ is only an estimate, as charge differences and branching of the polysaccharide chain can lead to a higher apparent mol. wt. Thus the PS-DT conjugate seen in the Coomassiestained gel probably has a low number of low mol.wt PS sub-units attached while the more sensitive Western blot shows PS-DT conjugate with a range of numbers of PS sub-units attached. Serovar pomona PS-DT conjugate containing $2 \cdot 4 \mu \mathrm{g}$ of carbohydrate-equivalent had approximately the same amount of carbohydrate as $5 \mu \mathrm{g}$ of LPS but the PS-DT conjugate stimulated antibody titres which were 15-100 times higher than those elicited by the equivalent amount of LPS. The hardjo conjugate had the same amount of carbohydrate as the pomona conjugate, $2.4 \mu \mathrm{g}$ of carbohydrateequivalent being approximately equal to $6.7 \mu \mathrm{g}$ of hardjo LPS. The difference was due to the composition of the LPS; pomona has a higher carbohydrate content than hardjo (data not shown). This PS-DT conjugate also stimulated 40 times the antibody titres produced by the LPS. Conjugation to antigenic carrier proteins has been used to confer both greater immunogenicity and T-cell-dependent properties on carbohydrate antigens from various different bacteria ${ }^{15-18}$ and we have shown this approach to be feasible for Leptospira.

As previously noted, the response of mice to pomona PS-DT conjugate was much higher than the response to hardjo conjugate, despite the use of 
equivalent amounts of LPS or equal amounts of carbohydrate as PS linked to DT. Future detailed structural and chemical analysis of reactive epitopes of PS may provide a better understanding of this difference in response.

Experimental infection has been prevented in animals with agglutinin titres as low as $2,{ }^{21,34}$ which suggests that the LPS of serovar pomona could possibly be used on its own as a protective vaccine; but this is not the case for serovar hardjo. Although leptospiral LPS does not possess endo-

\section{REFERENCES}

1. Adler B, Faine S. Epidemiology of human leptospirosis in Australia. Communicable Diseases Intelligence (Australian Department of Health) $1980 ; \mathbf{8 0}: 2-5$.

2. Blackmore DK, Schollum LM. Risks of contracting leptospirosis on the dairy farm. NZ Med J 1982; 95: 649652.

3. Adler B, Faine S. The antibodies involved in the human immune response to leptospiral infection. $J \mathrm{Med}$ Microbiol 1978; 11 : 387-400.

4. Adler B, Faine S. Serological and protective-antibody responses of rabbits to leptospiral antigens. $J \mathrm{Med}$ Microbiol 1978; 11; 401-409.

5. Faine S. Leptospiral antigens. Folia Facultatis Medicae, Universitatis Comenianae Bratislaviensis 1974; 12 Suppl : 57-74.

6. Vinh T, Adler B, Faine S. Ultrastructure and chemical composition of lipopolysaccharide extracted from Leptospira interrogans serovar copenhageni. J Gen Microbiol $1986 ; 132$ : 103-109.

7. Shimizu T, Matsusaka E, Nagakura $\mathrm{N}$ et al. Chemical properties of lipopolysaccharide-like substance (LLS) extracted from Leptospira interrogans serovar canicola strain Moulton. Microbiol Immunol 1987; 31 : 717-725.

8. Shimizu T, Matsusaka E, Takayanagi K et al. Biological activities of lipopolysaccharide-like substance (LLS) extracted from Leptospira interrogans serovar canicola strain Moulton. Microbiol Immunol 1987; 31: 727-735.

9. Jost B, Adler B, Vinh T, Faine S. A monoclonal antibody reacting with a determinant on leptospiral lipopolysaccharide protects guinea-pigs against leptospirosis. $J$ Med Microbiol 1986; 22: 269-275

10. Farrelly HE, Adler B, Faine S. Opsonic monoclonal antibodies against lipopolysaccharide antigens of Leptospira interrogans serovar hardjo. J Med Microbiol $1987 ; 23: 1-7$

11. Chapman AJ, Adler B, Faine S. Antigens recognised by the human immune response to infection with Leptospira interrogans serovar hardjo. J Med Microbiol 1988; 25 : 269-278.

12. Jost BH, Adler B, Faine S. Experimental immunisation of hamsters with lipopolysaccharide antigens of Leptospira interrogans. J Med Microbiol 1989; 29; 115-120.

13. Adler B, Faine S. Host immunological mechanisms in the resistance of mice to leptospiral infections. Infect Immun $1977 ; 17: 67-72$.

14. Avery O, Goebel W. Chemo-immunological studies on conjugated carbohydrate proteins. II. Immunological specificity of synthetic sugar-protein antigens. $J$ Exp Med 1929; 50: 533-550. toxic properties, ${ }^{35}$ potential adverse effects which may preclude its use as a vaccine have been reported. ${ }^{8}$ These effects might be obviated by the use of PS alone, and we have found that the poor immunogenicity of PS can be overcome by conjugation to DT. Further investigations into the sideeffects of these vaccines and their ability to protect against disease are thus warranted.

This work was supported by a grant from the National Health and Medical Research Council, Canberra, Australia.

15. Svenson S, Lindberg A. Immunochemistry of Salmonella Oantigens: preparation of an octasaccharide-BSA immunogen representative of Salmonella serogroup B Oantigen and characterization of the antibody response. $J$ Immunol 1978; 120: 1750-1757.

16. Schneerson R, Barrera O, Sutton A, Robbins JB. Preparation, characterization and immunogenicity of Haemophilus influenzae type b polysaccharide-protein conjugates. J Exp Med 1980; 152: 361-376.

17. Lambden P, Heckels J. Synthesis of immunogenic oligosaccharide-protein conjugates from the lipopolysaccharide of Neisseria gonorrhoeae P9. J Immunol Methods 1982; 48: $233-240$.

18. Cryz S, Sadoff J, Fürer E. Pseudomonas aeruginosa polysaccharide-tetanus toxoid conjugate vaccine: safety and immunogenicity in humans. $J$ Infect Dis 1986; 154 : $682-688$.

19. Christmas B, Till D, Bragger J. Dairy farm fever in New Zealand-isolation of Leptospira pomona and L. hardjo from a local outbreak. N Z Med J 1974; 79: 904-906.

20. Wolff J. The clarification of pathogenic leptospires. Symposium on the leptospires; Medical Science publication no. 1. US Government printing office, Washington DC, 1953: 174-185.

21. Adler B, Faine S. Susceptibility of mice treated with cyclophosphamide to lethal infection with Leptospira interrogans serovar pomona. Infect Immun 1976; 14: 703-708.

22. Adler B, Faine S. A pomona serogroup-specific, agglutinating antigen in Leptospira, identified by monoclonal antibodies. Pathology 1983; 15: 247-250.

23. Schneerson R, Robbins JB, Parke JC et al. Quantitative and qualitative analyses of serum antibodies elicited in adults by Haemophilus influenzae type $\mathrm{b}$ and pneumococcus type $6 \mathrm{~A}$ capsular polysaccharide-tetanus toxoid conjugates. Infect Immun 1986; 52 : 519-528.

24. Dubois M, Gilles KA, Hamilton JK, Rebers P, Smith F. Colorimetric methods for the determination of sugars and related substances. Anal Chem 1956; 28: 350-356.

25. Fattom A, Vann WF, Szu SC et al. Synthesis and physiochemical and immunological characterization of pneumococcus type $12 \mathrm{~F}$ polysaccharide-diptheria toxoid conjugates. Infect Immun 1988; 56: 2292-2298.

26. Bradford MM. A rapid and sensitive method for the quantitation of microgram quantities of protein utilising the principle of protein-dye binding. Anal Biochem $1976 ; 72: 248-254$

27. Laemmli U. Cleavage of structural proteins during the assembly of the head of bacteriophage T4. Nature 1970 ; 227: $680-685$.

28. Hitchcock PJ, Brown TM. Morphological heterogeneity 
among Salmonella lipopolysaccharide chemotypes in silver-stained polyacrylamide gels. J Bacteriol 1983; 154: $269-277$.

29. Burnette WN. "Western blotting": electrophoretic transfer of proteins from sodium dodecyl sulfate-polyacrylamide gels to unmodified nitrocellulose and radiographic detection with antibody and radio-iodinated protein $\mathrm{A}$. Anal Biochem 1981; 112: 195-203.

30. Hawkes R, Niday E, Gordon J. A dot-immunobinding assay for monoclonal and other antibodies. Anal Biochem 1982; 119: 142-147.

31. Christopher WL, Adler B, Faine S. Immunogenicity of leptospiral vaccines grown in protein-free medium. $J$ Med Microbiol 1982; 15: 493-501.
32. Mackintosh CG, Marshall RB, Broughton ES. The use of a hardjo-pomona vaccine to prevent leptospiruria in cattle exposed to natural challenge with Leptospira interrogans serovar hardjo. $N Z$ Vet $J 1980 ; 28$ : 174-177.

33. Vinh TU, Shi MH, Adler B, Faine S. Characterization and taxonomic significance of lipopolysaccharides of Leptospira interrogans serovar hardjo. J Gen Microbiol 1989; 135: $2663-2673$

34. Smith J. Vaccination of guinea-pigs and human beings against leptospiral infections. $J$ Hyg $1937 ; 37: 261-270$.

35. Vinh T, Adler B, Faine S. Glycolipoprotein cytotoxin from Leptospira interrogans serovar copenhageni. J Gen Microbiol 1986; 132: 111-123. 